\title{
Discussion on Applied Technique-oriented Talent Cultivation Mode of International Trading Specialty under the Background of Local Colleges Transformation
}

\author{
Tong Mei \\ Finance and Economics Department \\ College of Science and Technology \\ Nanchang University \\ Nanchang, China
}

\author{
Fangqin Chen \\ Finance and Economics Department \\ College of Science and Technology \\ Nanchang University \\ Nanchang, China \\ $\mathrm{Li} \mathrm{Xu}$ \\ Finance and Economics Department \\ College of Science and Technology \\ Nanchang University \\ Nanchang, China
}

\author{
Qiuyan Zhang \\ Finance and Economics Department \\ College of Science and Technology \\ Nanchang University \\ Nanchang, China \\ Mingmin Chen \\ Finance and Economics Department \\ College of Science and Technology \\ Nanchang University \\ Nanchang, China
}

\begin{abstract}
This paper proposes the transformation exploration from the aspects of renewing teaching materials, paying attention to practice teaching, increasing infrastructure investment, strengthening professional connection and updating test methods through discussion on the problems existing in current cultivation mode of international trading specialty in combination with the actual situation of transforming into applied technique-oriented colleges.
\end{abstract}

Keywords-transformation; international trading specialty; applied technique-oriented; talent cultivation

\section{INTRODUCTION}

In recent years, the State has stressed many times that we should strengthen modern vocational education. In February 2014, Premier Li Keqiang chaired a state council executive meeting and deployed to speed up the development of modern vocational education. In the same month, the state council executive meeting determined the measures to speed up modern vocational education development, one of which is to guide a group of ordinary colleges and universities transform into applied technique-oriented colleges. In March 2014, deputy minister of education, $\mathrm{Lu}$ Xin said on China Development Forum that, the 600 local colleges "upgraded"

This paper is a subject of "Research on Independent College Transformation from the Perspective of Professional Education" of 12th five-year educational plan in Jiangxi Province 2015, Subject No.: 15YB189 after expansion of university enrollment in 1999 will be transformed into modern vocational education gradually.

At present, considering the State encourages colleges transform into applied technique-oriented universities and there are difficulties in independent college development, we should seize the opportunity and innovate school running thought to transform the vocational and technical education to the applied technique-oriented university. This paper makes exploration on the cultivation mode of this specialty taking international trading specialty as an example under the background of applied talent cultivation mode, in order to find out an effective method for international trading teaching, and to promote the applied technique-oriented colleges to cultivate the characteristic international business talents meeting the market demand.

\section{MAIN PROBLEMS EXIST IN CURRENT INTERNATIONAL TRADING SPECIALTY}

\section{A. Teaching Material Content Is Serious Lagged Behind}

At present, most of the international trading specialties use the old teaching materials, and the data and information is updated slowly. And there is great gap with the reality especially in the aspects of trade terms and customs declaration 
and inspection. In order to adapt to the rapid development in modern information technology and other aspects, so that the students can be approachable for the job once they started work, we should update teaching content in a timely manner, and keep pace with the times.

\section{B. Focusing on Theoretical Knowledge in Teaching}

At present, most of the international trading specialties pay attention to theoretical knowledge in the teaching process. International trade specialty is a specialty with strong practicality, and if stress the theoretical knowledge blindly and ignore the business skill learning of international trading, it is very difficult to cultivate the applied skill-oriented international trading talents. Another reason is that some of the international trading specialty teachers haven't actually engaged in international trading work, as they work in the "school" directly after they graduated from "school", they have sufficient theoretical knowledge but lack of experience in terms of practice, which will result in their emphasizing of theoretical teaching.

\section{Imperfection of Teaching Infrastructure}

Currently, there are only a small number of laboratories in most of the international trading specialties, or even there is no a complete set of laboratory and corresponding professional software. Some colleges even failed to realize the multimedia teaching, and they still adopt the teaching way of typical blackboard and books. In such cases, students can only memorize mechanically the theoretical knowledge, having no way to grasp the practical knowledge, or to digest the various foreign trade segments using the professional knowledge they have acquired.

\section{Various Courses Are Not Closely Connected}

The professional courses established for international trading specialty include International Trade Practice, Custom Practice, Freight Forwarding, Business Correspondence and International Trade Documents, some of these courses are repeated, and there is the problem of insufficient connection. For example, International Trade Practice contains the knowledge about quotation, and Business Correspondence also contains the knowledge about quotation. However, the quotation of a commodity is not only influenced by production costs, expected profit and the trade terms, but also will be affected by the changes in exchange rate of the contract currency, international market situation, supply and demand, government policy changes, tariffs and non-tariff barriers and so on. But some of the courses are probably haven't been opened, so teachers can only explain the knowledge related to trade terms, and it is difficult to connect with other related knowledge.

\section{E. Single Exam Method of Various Courses}

Currently, most of the international trading specialties adopt close-book examination for the final test, which is relatively simple, and it could result in students' mechanically memorizing of theoretical knowledge prior to the examination, and cheat in the process of examination. After the test, it is easy to forget for them, lack of real understanding and mastering of foreign trade professional knowledge. As a result, they cannot get to work once they take up a working post in the future.

\section{EXPLORATION ON THE CULTIVATION MODE OF APPLIED TECHNIQUE-ORIENTED INTERNATIONAL TRADING SPECIALIZED TALENTS}

\section{A. Update the Teaching Material in A Timely Manner, Organize Relevant Professional Teachers to Supplement and Renew the Teaching Materials}

When determining the teaching material, the colleges should try to select the latest books considering the trading teaching materials are lagged behind in our country. And they can compile the characteristic teaching materials with their school characteristics, perfect contents, and meet the students' actual condition according to the reality and characteristics of students, as well as the updating and development of the current international trade. Or supplement the new rules and new knowledge related to international trade as the supplementary material for professional teachers in class. For example, at the end of 2015, China has signed the Free Trade Agreement with South Korea and Australia, yet it hasn't been compiled in the teaching materials, the colleges can organize teachers collect relevant data. In addition, the colleges can also organize teachers to compile appropriate bilingual teaching materials according to students' English level and characteristics.

\section{B. Pay Attention to Practice Teaching, and Combine Theory Teaching with Practice Teaching}

International trade specialty is a process-oriented specialty, which is reflected in the linked trading process. The pure theory teaching which lack of vitality cannot arouse students' interest. And students cannot conduct actual operation if they only master the theoretical knowledge. While explaining the international trading knowledge, teachers can make students feel concerned and master the theoretical knowledge through case teaching method, task driven teaching method and problem oriented teaching method, with the forms of specific cases, task completing and problem setting, coupled with the practice and operation of professional software, to achieve the objective of mastering both the theory and practice. In addition, the colleges can strengthen the construction of "doubleprofessionally-titled" teachers, to build a group of teachers for foreign trade with theoretical knowledge and extensive practical knowledge.

\section{Increase Investment in Teaching Facilities, and the Practice Platform for Applied Talent Cultivation}

The key for applied talent cultivation is to engage students in certain practice, to make the students directly connect with their expertise. Students specialized in international trading specialty should have the foreign trade business operating skills, foreign trade English application skills, market research ability and customer development skills, e-commerce skills and so on, there shall be clear target and reasonable methods for training of these skills. In addition, the relevant experimental fields and professional software are also needed. 
The colleges can establish the practice platforms both inside and outside school to train students' actual operation ability of foreign trade and the ability in coping with complex foreign trades through teachers' demonstration, software simulation, game competition, visiting, short-term internship, graduate internship and employment, to truly realize applied talent cultivation in the process of practice.

\section{Strengthen Cohesion among Professional Courses, and Teach according to the International Trade Process}

The specialization degree is high in various courses of international specialties, and there is close connection between the courses. The course may be set up according to the international trade process. For example, they can learn the International Trade Practice first, and then learn the International Business Correspondence, Customs Practice, finally the International Freight Forwarding. Thus the professional knowledge can be linked together through the process of international trade. In addition, the professional teacher shall communicate with each other to sort out the repeated contents and the related contents of various courses, to provide a targeted teaching, which is convenient for students to master.

\section{E. Establish Various Examination Methods, and Conduct Cross Examination within Various Professional Courses}

Students can be examined comprehensively through computer simulation, professional software testing, foreign trade dialogue, as well as foreign trade role playing and team cooperation. For example, as for the evaluation on International Trade Practice and International Freight Forwarding courses, students can act as the importers, exporters, shipping companies, insurance companies, banks and customs respectively in groups, and offer scores for group performance according to the specific procedures of foreign trade dialogue, credit opening, logistics and transportation, customs clearance, insurance, foreign trade documents submission, compensation claims, as well as documents examination and negotiation, etc., and add or reduce scores in combination with each of student's specific performance respectively on the basis of group scores.

\section{REFERENCES}

[1] Zhang Qisheng. Exploration on Application-oriented Talent Cultivation Mode of International Trading Specialty [J]. Chinese Talents, 2011, (7): 42-43.

[2] Su Hang. Study on International Trading Talent Cultivation Reform of Independent College - take the Humanities and Information College of Changchun University of Technology as an Example [J].Times Finance, 2013(10): 55-56.

[3] Li Xinzhong. Discussion on Teaching Method of Applied Techniqueoriented Colleges [J] . Technology Entrepreneurship, 2014,(4):131-132.

[4] Zhao Shaoquan. Analysis of the Problems Exist in International Trading Specialty Teaching in Part of the Present Colleges [J] . Journal of Beijing Union University (Natural Science Edition), 2005,(3): 80-83.

[5] Xu Jing. Study on International Trading Teaching Method Innovation [J]. Education for Chinese After-school, 2015, (9):128-129.

[6] Xing Saipeng, Tao Meisheng. Study on Faculty System Construction in Applied Technique-oriented Colleges-Based on the Perspective of
"Production-Teaching Integration and School-Enterprise Cooperation" [J]. Vocational \& Technical Education Forum, 2014, (29): 4-8.

[7] Wang Zhenliang, Shi Chen, Guo Heping. Analysis of Faculty Construction for Applied Technique-oriented College Education [J]. Theory Research,2014, (6):260-262. 